\title{
PENGARUH KONSUMSI RUMAH TANGGA, INVESTASI TERHADAP PERTUMBUHAN EKONOMI DI PROVINSI JAMBI
}

\author{
Sudirman, M. Alhudori \\ Fakultas Ekonomi, Universitas Batanghari
}

\begin{abstract}
This research is research that is literature research where the data used is data which have been researched by previous researcher, this research use time series data year 2005 - 2015. Where purpose of this research to see how influence from free variable (household consumption, investment) to the dependent variable (economic growth). hypothesis testing the influence of household consumption, investment, there is a significant relationship to economic growth in the province of jambi, this is adjusted to economic theory that economic growth will be explained by investment then this can be proven by using the F-test (collectively) and $t$-test (partially) with a 95\% confidence level or significance level $(\alpha=0.05)$ then the value of $F$-table is 4.07 whereas $F$ arithmetic is 9,422 thus the F statistic test criteria stated that F-count (9,422 )> from F-table (4.07), which means rejecting Ho and Ha accepted at a 95\% confidence level. This shows that together the independent variables significantly affect the economic growth.
\end{abstract}

Keywords: Economic Growth, Household Consumption, Investment

\section{PENDAHULUAN}

Menurut Sukirno (2008:423), bahwa dalam kegiatan perekonomian yang sebenarnya pertumbuhan ekonomi berarti perkembangan fiskal produk barang dan jasa yang berlaku di suatu negara, seperti pertambahan produksi barang industri, perkembangan infrastruktur, pertambahan jumlah sekolah, pertambahan produksi sektor jasa dan pertambahan produksi barang modal. Tetapi dengan menggunakan berbagai jenis data produksi adalah sangat sukar untuk memberikan gambaran tentang pertumbuhan ekonomi yang dicapai. Oleh sebab itu, untuk memberikan suatu gambaran kasar mengenai pertumbuhan ekonomi yang dicapai suatu negara, ukuran yang selalu digunakan adalah tingkat pertumbuhan pendapatan nasional riil yang dicapai. Pertumbuhan ekonomi juga bersangkut paut dengan proses peningkatan produksi barang dan jasa dalam kegiatan ekonomi masyarakat. Dapat dikatakan bahwa pertumbuhan menyangkut perkembangan yang berdimensi tunggal dan diukur dengan meningkatnya hasil produksi dan pendapatan.

PDB mengukur aliran pendapatan dan pengeluaran dalam perekonomian selama periode tertentu. Dalam perekonomian dua sektor aliran pengeluaran perekonomian terdiri dari dua komponen pengeluaran agregat, yaitu konsumsi rumah tangga, dan investasi. Pertumbuhan ekonomi berkaitan dengan proses peningkatan produksi barang dan jasa dalam kegiatan ekonomi masyarakat. Untuk mengukur pertumbuhan ekonomi, nilai PDB yang digunakan adalah PDB berdasarkan harga konstan (PDB riil) sehingga angka pertumbuhan yang dihasilkan merupakan pertumbuhan riil yang terjadi karena adanya tambahan produksi. Adanya keseimbangan dalam suatu perekonomian merupakan salah satu target dalam rangka peningkatan perekonomian suatu negara.

Hal tersebut dapat dicapai melalui keterlibatan variable ekonomi yang mempengaruhi dalam keseimbangan tersebut. Untuk melihat pertumbuhan 
ekonomi Provinsi Jambi dapat terlihat pada Tabel 1.

Tabel 1.

Pertumbuhan Ekonomi Provinsi Jambi Tahun 2005-2015

\begin{tabular}{ccc}
\hline Tahun & Pertumbuhan Ekonomi \% & \% \\
\hline 2005 & 5.57 & - \\
2006 & 5.89 & 5.74 \\
2007 & 6.82 & 6.62 \\
2008 & 7.16 & 4.98 \\
2009 & 6.38 & -10.89 \\
2010 & 7.34 & 15.04 \\
2011 & 8.54 & 16.34 \\
2012 & 7.44 & -12.88 \\
2013 & 7.88 & 5.91 \\
2014 & 7.34 & -6.85 \\
2015 & 7.84 & 6,81 \\
\hline
\end{tabular}

Sumber : Jambi dalam angka, 2016

Pada Tabel 1 dapat dilihat bahwa pertumbuhan ekonomi di Provinsi Jambi sejak periode 2005-2015 cenderung meningkat. Hal ini berkemungkinan dipengaruhi oleh perubahan konsumsi dan investasi yang juga cenderung mengalami peningkatan. Perubahan tersebut mampu mendorong pertumbuhan ekonomi Provinsi Jambi. Perubahan konsumsi tertinggi berada pada tahun

2012 sebesar 7,34\%. Seperti dapat dilihat pada tabel diatas, hal ini diduga penyebabnya adalah peningkatan konsumsi periode sebelumnya dan pendapatan disposabel.

Berikutnya perubahan konsumsi terendah berada pada tahun 2013 sebesar 4,05\%. Rendahnya perubahan konsumsi ini diduga bahwa perubahan konsumsi pada waktu yang sama tidak diiringi dengan perubahan pendapatan disposabel. Angka ini menunjukkan bahwa pada tahun 2007-2010, yang perubahan konsumsi berada di atas rata-rata, sedangkan pada tahun lainnya angka perubahannya justru berada di bawah nilai rata-rata. Sehingga dapat dikatakan bahwa perubahan konsumsi selama periode 2006,2011,2013,2014,2015 mengalami fluktuasi. Selain perubahan konsumsi, faktor lain yang mempengaruhi laju pertumbuhan ekonomi adalah investasi. Perubahan investasi Provinsi Jambi dari tahun 2005 sampai tahun 2012 mengalami peningkatan secara normal (Tabel 1.1). Seperti diketahui investasi berbanding terbalik terhadap suku bunga, apabila suku bunga rendah maka investasi akan banyak dan sebaliknya jika suku bunga turun maka akan semakin sedikit yang mau berinvestasi, hal ini diduga sebagai pemicu perubahan investasi.

Perubahan investasi tertinggi berada pada tahun 2013 sebesar 37,50\%. Tingginya angka investasi ini salah satunya mungkin disebabkan peningkatan pertumbuhan ekonomi, sehingga dapat menarik minat investor untuk melakukan investasi di Kota Padang. Idealnya, dengan tingginya tingkat investasi yang masuk ke Kota Padang tentunya akan mempertinggi tingkat pertumbuhan ekonomi Provinsi Jambi. Sedangkan pada tahun 2010 investasi Provinsi Jambi mengalami penurunan sebesar $4,52 \%$. Pada saat investasi mengalami penurunan, namun pertumbuhan ekonomi pada tahun 2006 ini masih mengalami peningkatan sebesar $5,12 \%$. Penurunan investasi tersebut diduga masih rendah kepercayaan 
investor untuk menanamkan modalnya di Provinsi Jambi, sebagai akibat dari tingginya tingkat persoalan masyarakat seperti birokrasi perizinan, dan masih banyaknya pungutan-pungutan liar atau pungli. Jika dilihat dari angka rata-rata perubahan investasi Provinsi Jambi selama kurun waktu dua tahun terakhir dari tahun 2010-2011 angka investasi berada di atas angka rata- rata. Kondisi ini tentunya merupakan peluang bagi pemerintah agar dapat menarik minat investor untuk menanamkan modalnya. Perubahan investasi berpengaruh positif terhadap pertumbuhan ekonomi, semakin tinggi investasi maka pertumbuhan ekonomi juga akan semakin membaik dan juga semakin banyaknya investasi akan membuka lapangan pekerjaan yang secara tidak langsung akan menyerap tenaga kerja. Kondisi ini akan mendukung pemerintah untuk meningkatkan fasilitas-fasiltas yang akan memudahkan para investor untuk menanamkan modalnya Konsumsi dan investasi adalah unsur yang paling esensial bagi sebuah perekonomian. Banyak alasan yang menyatakan analisis makro ekonomi perlu memperhatikan tentang konsumsi rumah tangga secara mendalam. Alasana pertama, konsumsi rumah tangga memberikan masukan kepada kepada pendapatan nasional. Di kebanyakan negara pengeluaran konsumsi sekitar 60-75 persen dari pendapatan nasional. Alasan kedua, konsumsi rumah tangga mempunyai dampak dalam menentukan fluktuasi kegiatan ekonomi dari satu waktu ke waktu yang lainnya. Konsumsi seseorang berbanding lurus dengan pendapatannya (Sukirno, 2003: 338).

\section{Landasan Teori}

\section{Pertumbuhan Ekonomi}

Sukirno (1996: 33), pertumbuhan dan pembangunan ekonomi memiliki definisi yang berbeda, yaitu pertumbuhan ekonomi ialah proses kenaikan output perkapita yang terus menerus dalam jangka panjang. Pertumbuhan ekonomi tersebut merupakan salah satu indikator keberhasilan pembangunan. Dengan demikian makin tingginya pertumbuhan ekonomi biasanya makin tinggi pula kesejahteraan masyarakat, meskipun terdapat indikator yang lain yaitu distribusi pendapatan. Sedangkan pembangunan ekonomi ialah usaha meningkatkan pendapatan perkapita dengan jalan mengolah kekuatan ekonomi potensial menjadi ekonomi riil melalui penanaman modal, penggunaan teknologi, penambahan pengetahuan, peningkatan ketrampilan, penambahan kemampuan berorganisasi dan manajemen. Pembangunan ekonomi didefinisikan dalam beberapa pengertian dengan menggunakan bahasa berbeda oleh para ahli, namun maksunya tetap sama.

Menurut Adam Smith pembangunan ekonomi merupakan proses perpaduan antara pertumbuhan penduduk dan kemajuan teknologi (Suryana, 2000:55). Todaro (dalam Lepi T. Tarmidi, 1992:11) mengartikan pembangunan sebagai suatu proses multidimensional yang menyangkut perubahan-perubahan besar dalam struktur sosial, sikap masyarakat, kelembagaan nasional maupun percepatan pertumbuhan ekonomi, pengurangan ketidakmerataan dan penghapusan dari kemiskinan mutlak. Pembangunan ekonomi menurut Irawan (2002: 5) adalah usaha-usaha untuk meningkatkan taraf hidup suatu bangsa yang seringkali diukur dengan tinggi rendahnya pendapatan riil perkapita.

Meier (dalam Adisasmita, 2005: 205) mendefinisikan pembangunan ekonomi sebagai proses kenaikan pendapatan riil perkapita dalam suatu jangka waktu yang panjang. Sukirno (1985:13) mendefinisikan pembangunan ekonomi 
sebagai suatu proses yang menyebabkan pendapatan perkapita penduduk suatu masyarakat meningkat dalam jangka panjang. Definisi tersebut mengandung pengertian bahwa pembangunan ekonomi merupakan suatu perubahan yang terjadi secara terus-menerus melalui serangkaian kombinasi proses demi mencapai sesuatu yang lebih baik yaitu adanya peningkatan pendapatan perkapita yang terus menerus berlangsung dalam jangka panjang.

Menurut Schumpeter dalam Suryana (2000:5), pembangunan ekonomi bukan merupakan proses yang harmonis atau gradual, tetapi merupakan perubahan yang spontan dan tidak terputus-putus. Pembangunan ekonomi disebabkan oleh perubahan terutama dalam lapangan industri dan perdagangan. Pembangunan ekonomi berkaitan dengan pendapatan perkapita dan pendapatan nasional. Pendapatan perkapita yaitu pendapatan rata-rata penduduk suatu daerah sedangkan pendapatan nasional merupakan nilai produksi barang-barang dan jasajasa yang diciptakan dalam suatu perekonomian di dalam masa satu tahun. Pertambahan pendapatan nasional dan pendapatan perkapita dari masa ke masa dapat digunakan untuk mengetahui laju pertumbuhan ekonomi dan juga perkembangan tingkat kesejahteraan masyarakat suatu daerah. Dalam pengertian pembangunan ekonomi yang dijadikan pedoman adalah sebagai suatu proses yang menyebabkan pendapatan perkapita penduduk suatu masyarakat meningkat dalam jangka panjang. Sementara itu pertumbuhan ekonomi menurut.

Kuznets (dalam Jhingan, 2000: 57), adalah kenaikan jangka panjang dalam kemampuan suatu negara untuk menyediakan semakin banyak jenis barangbarang ekonomi kepada penduduknya. Kemampuan ini tumbuh sesuai dengan kemajuan teknologi, dan penyesuaian kelembagaan dan idiologis yang diperlukannya. Definisi ini mempunyai 3 (tiga) komponen: pertama, pertumbuhan ekonomi suatu bangsa terlihat dari meningkatnya secara terus-menerus persediaan barang; kedua, teknologi maju merupakan faktor dalam pertumbuhan ekonomi yang menentukan derajat pertumbuhan kemampuan dalam penyediaan aneka macam barang kepada penduduk; ketiga, penggunaan teknologi secara luas dan efisien memerlukan adanya penyesuaian di bidang kelembagaan dan ideologi sehingga inovasi yang dihasilkan oleh ilmu pengetahuan umat manusia dapat dimanfaatkan secara tepat.

\section{Investasi}

Investasi menurut Fitzgeral, Investasi adalah suatu aktivitas yang berhubungan dengan usaha penarikan sumber-sumber (dana) yang dipakai untuk mengadakan barang modal pada saat sekarang dan dengan barang modal akan dihasilkan aliran produk baru di masa yang akan datang. Dari definisi ini investasi dikonstruksikan sebagai sebuah kegiatan untuk : (1) Penarikan sumber dana yang digunakan untuk pembelian barang modal; (2) Barang modal itu akan dihasilkan produk baru.

Kamaruddin Ahmad, Pengertian Investasi adalah menempatkan uang atau dana dengan harapan untuk memperoleh tambahan atau keuntungan tertentu atas uang atau dana tersebut. Pengertian investasi ini menekankan pada penempatan uang atau dana. Tujuan investasi ini adalah untuk memperoleh keuntungan. Hal ini erat kaitannya dengan penanaman investasi di bidang pasar modal. Salim HS dan Budi Sutrisno mengemukakan pengertian investasi, Investasi ialah penanaman modal yang dilakukan oleh investor, baik investor asing maupun domestik dalam berbagai bidang usaha yang terbuka untuk investasi, yang bertujuan untuk 
memperoleh keuntungan.

Pengertian Investasi dalam Ensiklopedia Indonesia, Investasi yaitu penanaman modal atau penanaman uang dalam proses produksi dengan membeli gedung-gedung, mesin-mesin, bahan-bahan cadangan, penyelenggaraan uang kas serta perkembangannya. Dalam hal ini cadangan modal barang diperbesar selama tidak ada modal barang yang harus diganti. Hakikat investasi dalam definisi ini adalah penanaman modal yang dipergunakan untuk proses produksi. Dalam hal ini investasi yang ditanamkan hanya digunakan untuk proses produksi saja. kegiatan investasi dalam realitanya tidak hanya dipergunakan untuk proses produksi, tetapi juga pada kegiatan untuk membangun berbagai sarana dan prasarana yang dapat menunjung kegiatan investasi. Selanjutnya Kamarauddin memberikan pengertian investasi dalam tiga artian, yaitu :

1. Investasi yaitu suatu tindakan untuk membeli saham, obligasi atau suarat penyertaan lainnya.

2. Investasi merupaan suatu tindakan untuk membeli barang-barang modal.

3. Investasi adalah pemanfaatan dana yang tersedian untuk dipergunakan dalam produksi dengan pendapatan di masa yang akan datang.

Dalam definisi ini, investasi dikonstruksikan sebagai tindakan membeli saham, obligasi dan barang-barang modal. Hal ini erat kaitannya dengan pembelian saham pada pasal modal, padahal penanaman investasi tidak hanya dipasar modal saja, tetapi juga diberbagai bidang lainnya seperti di bidang pariwisata, pertambangan minyak dan gas bumi, pertanian, kehutanan dan lain sebagainya. Isilah Investasi sendiri berasal dari kata investire yang berarti memakai atau menggunakan. Investasi adalah memberikan sesuatu kepada orang lain untuk dikembangkan dan hasil dari sesuatu yang dikembangkan tersebut akan dibagi sesuai dengan yang diperjanjikan.

Investasi dapat dibagi menjadi dua macam yaitu investasi asing dan investasi domestik. Investasi Asing adalah investasi yang bersumber dari pembiayaan luar negeri, sedangkan Investasi Domestik ialah investasi yang bersumber dari pembiayaan dalam negeri. Investasi pada umumnya digunakan untuk pengembangan usaha yang terbuka dan tujuan investasi tersebut untuk memperoleh keuntungan di masa yang akan dating.

\section{Konsumsi Rumah Tangga}

Secara luas, definisi konsumsi mengambil istilah dari dua bahasa yang berbeda, yaitu Bahasa Belanda dan Bahasa Inggris. Dalam istilah dari Bahasa Belanda, konsumsi berasal dari kata consumptie yaitu segala kegiatan yang dipergunakan dengan tujuan untuk mengambil kegunaan pada suatu produk dan jasa. Sedangkan dari Bahasa Inggris, konsumsi berasal dari kata consumption yang berarti pemakaian, menggunakan, pemanfaatan, dan atau pengeluaran. Seperti yang diketahui, cakupan konsumsi ini sangat luas dan tidak terbatas hanya pada satu benda maupun jasa tertentu. Jika dijabarkan kedalam penjelasan ekonomi makro, maka konsumsi dapat diartikan sebagai variabel makro ekonomi yang dilambangkan dengan huruf "C" yaitu singkatan dari consumption. Consumption disini dikategorikan ke dalam klasifikasi konsumen rumah tangga, yaitu pembelanjaan barang atau jasa dengan tujuan untuk memenuhi kebutuhan atau melakukan pembelian berdasarkan pendapatan yang dimiliki atau diperoleh. Ketika kegiatan konsumsi itu tidak menghabiskan seluruh pendapatan yang dihasilkan, maka sisa uang yang dimiliki disebut sebagai tabungan. Tabungan ini 
dilambangkan dengan huruf "S" yaitu singkatan dari kata saving dalam Bahasa Inggris. Jika dilihat dalam perhitungan makro, maka perhitungan dari penjumlahan seluruh pengeluaran-pengeluaran belanja dan konsumsi masingmasing rumah tangga dalam cakupan satu negara disebut sebagai pengeluaran konsumsi masyarakat suatu negara.

Mengapa analisis makro ekonomi menghitung berdasarkan perhitungan belanja konsumsi rumah tangga? Terdapat beberapa alasan mengapa menggunakan perhitungan belanja konsumsi rumah tangga, yaitu alasan pertama adalah karena konsumsi rumah tangga telah memberikan pemasukan yang besar untuk pendapatan suatu negara. Alasan yang kedua adalah pertimbangan bahwa besarnya pengeluaran untuk konsumsi berbanding lurus dengan besarnya pendapatan yang diperoleh. Sehingga semakin besar pendapatan yang dimiliki, maka semakin besar pula jumlah pengeluaran konsumsi yang dilakukan oleh suatu rumah tangga. Hal inilah yang mempengaruhi besaran fluktuasi kegiatan ekonomi suatu negara dari waktu ke waktu.

Teori konsumsi Keynes mengedepankan tentang analisis perhitungan statistik, serta membuat hipotesa berdasarkan observasi kasual. Keynes menganggap perhitungan fluktuasi ekonomi negara dapat dihitung berdasarkan besarnya konsumsi dan pendapatan belanja rumah tangga. Pada pengeluaran rumah tangga, selalu terdapat pengeluaran untuk konsumsi walaupun tidak memiliki pendapatan. Hal ini disebut sebagai pengeluaran konsumsi otonomus atau autonomus consumption.

Keynes memiliki teori konsumsi absolut yang disebut sebagai Teori Konsumsi Keynes (absolut income hypothesis). Keynes berpendapat bahwa besarnya konsumsi rumah tangga, tergantung dari pendapatan yang dihasilkan. Perbandingan antara besar nya konsumsi dan pendapatan disebut Keynes sebagai Marginal Propensity to Consume (MPC). MPC ini digunakan untuk mengukur bahwa semakin besar pendapatan yang dimiliki, maka tingkat konsumsi rumah tangga juga tinggi, dan begitu pula sebaliknya.

Untuk menjelaskan teori Keynes tersebut, maka perlu dibuat rancangan perhitungan pendapatan dan konsumsi melalui Teori Konsumsi dengan Hipotesis Pendapatan Absolut. Teori tersebut menyatakan bahwa jumlah pengeluaran konsumsi berkaitan erat dengan pendapatan negara yaitu dapat mempengaruhi fluktuasi perekonomian negara, dimana hal tersebut dapat diukur berdasarkan harga konstan.

Fungsi Konsumsi Keynes adalah $\mathrm{C}=\mathrm{Co}=c \mathrm{Yd}$. Dimana Co adalah konsumsi otonom (The Autonomus Consumption). Dan Yd adalah pendapatan yang bisa digunakan untuk konsumsi. Rumus Yd adalah Y - Tx + Tr. Dimana Tx adalah pajak, dan $\operatorname{Tr}$ adalah subsidi atau transfer. Dari rumus tersebut dapat diperoleh rata-rata konsumsi atau Average Propensity to Consume (APC) yaitu perbandingan jumlah konsumsi dibandingkan dengan pendapatan. Kemudian jika terjadi perubahan yaitu tambahan pendapatan sehingga menambah jumlah konsumsi, maka dapat dihitung dengan Marginal Propensity to Consume atau perubahan konsumsi yang terjadi karena pendapatan yang meningkat.

\section{METODE}

Penelitian ini digunakan metode penelitian deskriptif kuantitatif. Metode penelitian kuantitatif digunakan dalam upaya mengetahui perkembangan pertumbuhan ekonomi, konsumsi rumah tangga dan investasi di Provinsi Jambi. 
Data yang digunakan adalah data skunder yaitu data yang berupa data yang tersedia pada lembaga-lembaga resmi pemerintah, diantaranya :

1. PDRB Provinsi Jambi Tahun 2005 - 2015 (BPS Provinsi Jambi)

2. Konsumsi Rumah Tangga tahun 2005 - 2015 (BPS Provinsi Jambi)

3. Investasi di provinsi Jambi tahun 2005 - 2015 (BPS Privinsi Jambi)

Pengumpulan data dalam penelitian ini digunakan metode library research yaitu menggunakan metode kepustakaan dengan mempelajari buku-buku literatur, jurnal penelitian, atau artikel serta sumber lainnya yang relevansi dengan pokok bahasan dalam penelitian ini. Pengolahan data untuk regresi menggunakan program SPSS versi 20.0.

\section{Metode Analisis}

\section{Model Analisis Kuantitatif}

Model analisis yang digunakan dalam penelitian ini adalah menggunakan alat analisis kuantitatif dengan menggunakan model ekonometrika regresi berganda sebagai berikut :

$\mathbf{Y}=\mathbf{a}+\boldsymbol{\beta} o+\boldsymbol{\beta}_{1} \mathbf{X}_{1}+\boldsymbol{\beta}_{2} \mathbf{X}_{2}+\mathbf{e}$

Keterangan :

$\mathrm{Y} \quad=$ Pertumbuhan Ekonomi.

Bo $=$ Konstanta

$\mathrm{X}_{1} \quad=$ Konsumsi Rumah Tangga ( Rupiah )

$\mathrm{X}_{2} \quad=$ Investasi (Rupiah)

$\beta_{1}, \beta_{2}=$ Koefisien Regresi ( Elastisitas )

e $\quad=$ Standar Error

\section{Pengujian Hipotesis}

Untuk mengetahui bagaimana pengaruh pariabel-variabel bebas yaitu $\mathrm{X}_{1}$ (konsumsi rumah tangga), $\mathrm{X}_{2}$ (investasi), baik secara simultan maupun parsial digunakan metode (Yuwono 2004; 60) :

Secara parsial dengan menggunakan Uji - $t$

untuk menguji keberartian koifisiaen regresi yang ditaksir secara parsial dengan menggunakan rumus :

$t_{i}=\frac{\beta \tau}{S_{e}(\beta \tau)}$

Setelah diproleh nilai uji-t yang ditaksir kemudian dibandingkan dengan ttabel menggunakan hipotesis sebagai berikut :

1. Ho : $\beta=0$, berarti tiadak ada pengaruh konsumsi rumah tangga terhadap pertumbuhan ekonomi

2. Ha : $\beta \# 0$ berti terdapat pengruh konsumsi terhadap pertumbuhan ekonomi

Pengujian ini dilakukan dengan membandingkan nilai t yang diperoleh dari hasil uji statistik dengan nilai $t$ terdapat pada tabel distribusi dengan syarat :

Jika t-hitung $\leq \mathrm{t}$-tabel, maka hipotesa nol diterima dan hipotesa alternatif ditolak berrati hubungan antara variabel bebas dengan variabel tidak bebas tidak signifikan.

Jika t-hitung $\geq$ t-tabel, maka hipotesa nol ditolak dan hipotesa alternatif diterima berarti hubungan antara variabel bebas dengan variabel tidak bebas signifikan.

Secara simultan dengan menggunakan Uji F 
Pada khususnya regresi berganda, uji $\mathrm{F}$ dilakukan guna mengetahui signivikan tidaknya pengaruh Variabel-variabel bebas, yaitu $\mathrm{X}_{1}$ (konsumsi rumah tangga), $X_{2}$ (investasi), secara simultan terhadap pariabel terikat $(\gamma=$ pertumbuhan ekonomi ).

Pengujian ini dilakukan dengan mebandingkan antar nilai F-hitung dengan Nilai F-tabel. Maka F-hitung dengan $\mathrm{R}^{2}$ diperoleh dengan cara :

$$
F_{h}=\frac{R^{2} /(k-1)}{\left(1-R^{2}\right) / n-k}
$$

Keterangan:

$\mathrm{R}^{2}=$ Koifisien determinasi

$\mathrm{k}=$ Jumlah variabel yang diestimasi

$\mathrm{n}=$ Jumlah sampel berikut:

Pengujian ini jika diwujudkan dalam bentuk hipotesa adalah sebagai

$\mathrm{H}_{0}: \mathrm{B}_{1 \ldots \ldots \ldots . . .} \mathrm{B}_{4}=\mathrm{O}$, berarti ada pengaruh dari seluruh variabel bebas secara bersama - sama terhadap pariabel bebas.

$\mathrm{H}_{0}: \mathrm{B}_{1 \ldots \ldots \ldots \ldots} \mathrm{B}_{4} \neq \mathrm{O}$, berati ada pengaruh dari seluruh variabel bebas secara bersama - sama terhadap variabel bebas.

Untuk menentukan keputusan dapat dilakukan sebagai berikut:

Jika F- hitung $\leq$ F- tabel, maka hipotesa nol diterima dan hipotesa alternatif ditolak berarti secara keseluruhan tidak ada hubungan antara variabel bebas dengan variabel tidak bebas ( signifikan ).

Jika F- hitunf $\geq$ F- tabel , maka hipotesa nol ditolak alternativ diterima berarti secara keseluruhan terdapat hubungan antara variabel bebas dengan variabel tidak bebas (signifikan)

\section{Koefinsien Determinasi}

Koifisien determinasi, $\mathrm{R}^{2}$ adalah bilangan yang menyatakan persentasi varitas total $\mathrm{Y}$ yang dijelaskan oleh garis regresi koefisien ini dapat diproleh dari rasio varians $\mathrm{Y}$ dengan varians $\mathrm{Y}$.

$$
R^{2}=1-\frac{\sum e^{2}}{\sum y^{2}}
$$

Rumus tersebut memiliki 3 penjelasan:

1. Angka 1 menyatakan maksimum dengan varitas total $\mathrm{Y}$ yang dijelaskan oleh garis regresi $100 \%$ yaitu pada saat $\Sigma \mathrm{e}^{2}=0$ dan minimum pada saat $\Sigma \mathrm{e}^{2}=\Sigma \mathrm{y}^{2}$. jadi nilai koifisien determinasi berkisar 0 dan $1,0<\mathrm{R}^{2}<1$.

2. $\Sigma \mathrm{e}^{2}=\Sigma \mathrm{y}^{2}$ adalah nilai yang menyatakan varitas totalnya $\mathrm{Y}$ yang tidak dijelaskan regresinya.

3. Koefisien determinasi sama dengan $100 \%$ dikrangi dengan varitas total Y yang tidak dijelaskan garis regresinya

\section{HASIL}

Berdasarkan hasil analisis regresi di atas di peroleh nilai koifesien regresi konstanta sebesar 0,015 artinya jika konsumsi rumah tangga, investasi, adalah konstan maka pertumbuhan ekonomi sebesar 0.015.

$$
\begin{gathered}
\mathbf{Y}=\boldsymbol{\beta o}+\boldsymbol{\beta}_{1} \mathbf{X}_{1}+\boldsymbol{\beta}_{2} \mathbf{X}_{2}+\mathbf{e} \\
\text { t-hitung }=
\end{gathered}
$$




$$
\begin{array}{lll}
\mathrm{R}^{2}=0,702 & \text { F-hitung }=9.422 & \text { F-tabel }=4.07 \\
\mathrm{R}=0,838 & \text { t-tabel }=1.833 &
\end{array}
$$

Nilai koefisien konsumsi rumah tangga $\left(\mathrm{X}_{1}\right)$ sebesar $-0,065$ artinya jika konsumsi rumah tangga $\left(\mathrm{X}_{1}\right)$ naik sebesar $1 \%$ maka pertumbuhan ekonomi akan turun sebesar $-0,065 \%$ hal ini menunjukan adanya kecendrungan yang negatif antara konsumsi rumah tangga terhadap pertumbuhan ekonomi. Nilai koefisien investasi $\left(\mathrm{X}_{2}\right)$ sebesar 0,338 artinya jika investasi naik sebesar $1 \%$ maka pertumbuhan ekonomi meningkat sebesar $0.338 \%$ hal ini berpengaruh positif di karenakan investasi mempunyai sebuah garis linier terhadap pertumbuhan ekonomi di Provinsi Jambi maka cendrung meningkatkan PDRB sektor ekonomi.

\section{Analisis Korelasi dan Determinasi}

Untuk melihat besarnya pertumbuhan ekonomi sebagai variable terikat terhadap konsumsi rumah tangga, investasi, sebagai variable bebas maka dapat dilihat dari nilai koefisien korelasi $\left(\mathrm{R}^{2}\right)$ sebesar 0,702 artinya terdapat hubungan yang sangat kuat antara pertumbuhan ekonomi di Provinsi Jambi dengan konsumsi rumah tangga, investasi. Untuk nilai koefisien determinasi $(\mathrm{R})$ sebesar 0,838 artinya $83,8 \%$ variasi perubahan nilai $\mathrm{Y}$ (pertumbuhan ekonomi) dapat dijelaskan oleh perubahan variabel konsumsi rumah tangga $\left(\mathrm{X}_{1}\right)$, investasi $\left(\mathrm{X}_{2}\right)$, dan sisanya sebesar $16.2 \%$ disebabkan oleh faktor - faktor lain yang tidak dibahas dalam model ini.

\section{Uji Hipotesis \\ Uji Parsial (t-test)}

Berdasarkan uji-t untuk mengetahui secara varsial pengaruh variable terikat terhadap variable bebas, uji ini dilakukan pada degree ofreedom (df) dengan derajat keyakinan sebesar $95 \%(\mathrm{a}=5 \%)$ maka diperoleh $\mathrm{t}$ - tabel sebesar 1,833. yang dibandingkan dengan t-hitung, jika t-hitung $>\mathrm{t}$-tabel maka tedapat pengaruh yang signifikan antara variable bebas terhadap variable terikat sehingga (Ho) ditolak Dan $\left(\mathrm{H}_{\mathrm{a}}\right)$ diterima, sedangkan jika t-hitung < t-tabel maka tidak dapat pengaruh yang signifikan antara variable terikat dengan variable bebas sehingga (Ho) diterima Dan $\left(\mathrm{H}_{\mathrm{a}}\right)$ ditolak. Hasil penghitungan secara parsial di peroleh nilai t-hitung untuk pendidikan sebesar 0,067.

1. Nilai $\mathrm{t}$ - hitung untuk $\mathrm{X}_{1}$ (konsumsi rumah tangga) sebesar -1.115 sedangkan nilai t tabel pada taraf signifikan (a) sebesar 0,05 dengan degree of freedom (df) $=10-1-1=8$ yaitu sebesar 1,833. karena t hitung $-1,115<\mathrm{t}$-tabel 1,833 maka hipotesis (Ha) ditolak maka hipotesis (Ho) diterima. Dengan demikian hipotesis yang menyatakan bahwa konsumsi rumah tangga tidak memiliki mempengaruhi yang positif terhadap pertumbuhan ekonomi.

2. Nilai $t$ - hitung $X_{2}$ ( investasi ) sebesar 3.183 sedangkan nilai $t$ - tabel pada taraf signifikan (a) sebesar 0,05 dengan degree of freedom (df) $=10-1-1$ yaitu sebesar 1,833. karena $\mathrm{t}$ - hitung 3.163> $\mathrm{t}$ - tabel 1,833 maka hipotesis (Ha) diterima dan hipotesis alternatif (Ho) ditolak. Dengan demikian maka hipotesis yang mengatakan bahwa terdapat pengaruh / kaitan yang signifikan antara variabel investasi (X2) terdapat pertumbuhan ekonomi.

\section{Uji Overall (F-test)}

Uji signifikasi dilakukan dengan menggunakan uji-F (secara bersama-sama ) dan uji-t (secara parsial) dengan tingkat kepercayaan $95 \%$ atau level signifikance 
$(\alpha=0,05)$ maka diproleh nilai $F_{\text {tabel }}$ sebesar 4.07 sedangkan $F_{\text {hitung }}$ sebesar 9.422 dengan demikian kriteria uji $F$ statistik dinyatakan bahwa $F_{\text {hitung }}(9.422)>$ dari $\mathrm{F}_{\text {tabel }}(4.07$ ), yang berarti menolak Ho dan Ha diterima pada tingkat keyakinan 95 $\%$. Hal ini menunjukan bahwa secara bersama-sama variabel bebas berpengaruh nyata terhadap pertumbuhan ekonomi dan hal ini menunjukan bahwa hipotesis terbukti.

\section{SIMPULAN}

Berdasarkan hasil penelitian dan pembahasan yang dilakukan untuk menganalisa pengaruh konsumsi rumah tangga, investasi dan pertumbuhan ekonomi di Provinsi Jambi, maka dapat disimpulkan bahwa :

1. Perkembangan pertumbuhan ekonomi di Provinsi Jambi berpluktuatif dengan rata-rata pertahun $7,10 \%$, sedangkan perkembangan konsumsi rumah tangga cendrung meningkat dalam kurun waktu 10 tahun dengan rata-rata pertahun adalah sebesar $5,12 \%$, sementara itu perkembangan investasi cendrung menurun dan rata-rata pertahunnya adalah $15,25 \%$

2. Berdasarkan dari hasil pengujian hipotesis pengaruh konsumsi rumah tangga, investasi, terdapat hubung yang signifikan terhadap pertumbuhan ekonomi di provinsi jambi, hal ini disesuaikan dengan teori ekonomi bahawa pertumbuhan ekonomi akan dijelaskan oleh investasi maka hal ini dapat dibuktikan dengan menggunakan uji-F (secara bersama - sama ) dan uji-t (secara parsial) dengan tingkat kepercayaan $95 \%$ atau level signifikance $(\alpha=0,05)$ maka diproleh nilai F-tabel sebesar 4,07 sedangkan $\mathrm{F}$ hitung sebesar 9,422 dengan demikian kriteria uji F statistik dinyatakan bahwa F- hitung ( 9,422 ) > dari F- tabel ( 4,07), yang berarti menolak Ho dan Ha diterima pada tingkat keyakinan $95 \%$. Hal ini menunjukan bahwa secara bersama - sama variabel bebas berpengaruh nyata terhadap pertumbuhan ekonomi.

\section{DAFTAR PUSTAKA}

Arikunto, Suharsimi. 2006. Prosedur Penelitian Suatu Pendekatan Praktik. Jakarta: Rineka Cipta.

Berutu, Reza Monandar. 2009. Pengaruh APBD Terhadap Pertumbuhan Ekonomi di Kabupaten Dairi. (Skripsi). Medan. Universitas Sumatera Utara. Sripsi dipublikasikan.

Ghozali, Imam. 2011. Aplikasi Analisis Multivariat dengan Program SPSS. Semarang: Badan Penerbitan Universitas Diponegoro.

Herlambang, Tedy, DKK. 2001. Ekonomi Makro (Teori, Analisi dan Kebijakan). Jakarta. PT Gramedia.

Jhingan.M.L, 2004, Ekonomi Pembangunan Dan Perencanaan, , PT Raja Grafindo Persada, Jakarta.

Mankiw, N. Gregory, 2003. Teori Makro Ekonomi. Edisi keempat. Jakarat: Erlangga.

Putra, Norista Gathama. 2011. Pengaruh Belanja Modal dan Belanja Operasi Terhadap Laju Pertumbuhan Ekonomi di Provinsi Jawa Tengah. (Skripsi). Semarang; Universitas Diponegoro. Skripsi dipublikasikan.

Reksoprayitno, soediyono. 2000. Ekonomi Makro (pengantar analisis pendapatan nasional. Edisi kelima, cetakan kedua. Yogyakarta: Liberty.

Samuelson, paul A. Nordhaus, Wiliam D. 1997. Ekonomi. Erlangga Jakarta. Shandra, Yosi. 2012. Konsumsi dan Investasi serta Pertumbuhan 
Ekonomi Sumtera Barat. Jurnal kajian ekonomi. Nolume 1, Nomor 1. Jurnal dipublikasikan.

Silvia, Engla Desnim, Dkk. 2013. Analisis Pertumbuhan Ekonomi, Investasi, dan Inflasi di Indonesia.Jurnal kajian ekonomi. Volume1, No 02. Jurnal dipublikasikan.

Sinuraya, Rosmawati. 2010. Analisis Pengaruh Pengeluaran Pemerintah terhadap pertumbuhan ekonomi Kabupaten Karo. (skripsi). Medan; Universitas Sumatera Utara. Skripsi dipublikasikan.

Siregar, Syofian. (2012). Statistik Deskriptif Untuk Penelitian. Jakarta: Raja Grafindo Persada.

Sukirno, Sadono. 2003. Makro Ekonomi Modern: Perkembangan Pemikiran dari Klasik Hingga Keynesian Baru, Jakarta: PT Raja Grafindo Persada.

---------------. 2008. Makro Ekonomi Modern: Perkembangan Pemikiran dari Klasik Hingga Keynesian Baru, Jakarta: PT Raja Grafindo Persada.

Swaramarinda, Dharma Rika. (2011). Pengaruh Pengeluaran Konsumsi dan Investasi Pemerintah terhadap Pertumbuhan Ekonomi di Indonesia. Jurnal Econo Sains, Volume IX, Nomor 2, Halan 104. Jurnal dipublikasikan.

Tambunan, Tulus T.H, 2001. Perekonomian Indonesia (Teori dan Temuan Empiris). Jakarta; Ghalia Indonesia.

Tarigan, Robinson. 2007. Ekonomi Regional Teori dan Aplikasi. Jakarta; Bumi Aksara.

Zuriah, Nurul. 2007. Metodologi Penelitian Sosial dan Pendidikan. Jakarta: Bumi Aksara. 